\title{
Experience of Spiritual Leaders' Interaction with Employees in Business Organisations
}

This article presents a study, the goal of which is to reveal experience of the spiritual leader's interaction with employees in business organisations. The study is based on P. Ricoeur's (2000) interpretations and the phenomenological hermeneutics method by A. Lindseth (2004) and A. Norberg (2004) dedicated to the interpretation of interviews. The article presents findings on the interaction of the leader and his/her followers in mid-sized Lithuanian organisations' culture, i.e., managers' experiences arising from their core assumptions and revealed through targeted actualisation of employee activities, satisfaction, meaningful work, experience of organisational identity, leader-instigated sense of community and appreciation, and employee awareness. Keywords: phenomenological hermeneutics, spiritual leader, leadership and organisational culture.

Straipsnyje pristatomas kokybinis tyrimas, kurio tikslas - atskleisti dvasingų vadovų sąveikos su darbuotojais organizacijose patirtis. Tyrimas aprašomas remiantis Paul Ricoeur interpretacijos teorijos paremtu A. Lindseth (2004) ir A. Norberg (2004) fenomenologiniu-hermeneutiniu metodu, skirtu interviu tekstams interpretuoti. Tyrimo rezultatas - lyderio ir sekèjų sąveika Lietuvos vidutinio dydžio organizacijų kultūroje, t. y. vadovų patirtys, igyjamos iš jų kertinių prielaidų bei atsiskleidusios per: kryptingą darbuotojų veiklos iprasminimą, pasitenkinimą, prasmingą darbą, organizacinio tapatumo potyrị, lyderio įveiklintą bendruomeniškumą, supratimą ir ịvertinimą, darbuotojų sąmoningumą.

Raktiniai žodžiai: fenomenologinè hermeneutika, dvasingi vadovai, lyderystė, organizacijų kultūra.

\section{Introduction}

According to G. W. Fairholm (1998), leaders cannot act as spiritual leaders or any other kind of leaders if they are in a leadership vacuum. It is a dynamic process, which through unique means incorporates the model's elements. According to V. Šilingienè (2012), with the appearance of a new paradigm of leadership theories, the range of leadership has been extended by the emotional, social, ethnic and moral aspects of impact on followers. They merge sociology, psychology, philosophy and create a new definition of leadership, using three main aspects: personal (leadership as self-improvement; as a way of life and thought), interrelationship (leadership as interaction with followers; ability to create a vision), and organisational (leadership as initiation of changes; creating an organisation). According to A. Skaržauskiené (2010), based on modern leadership theories V. Barvydienè (2015) describes leadership in four aspects: strength of personality, interaction with followers, vision focused

Rasa KATILIENE - doctor of social sciences, certified spiritual intelligence coach, lecturer at K. Simanavičius university. Address: Dariaus ir Gireno str. 21, Vilnius, Lithuania. E-mail: rasa@katiliene.eu. 
on certain values, and performance. The previous leadership theories have focused in varying degrees on one or more aspects of the physical, mental, or emotional elements of human interaction in organizations neglecting the spiritual component.

J. L. Fry (2003) defines spiritual leadership as comprising the values, attitudes, and behaviours that are necessary to intrinsically motivate one's self and others so that they have a sense of spiritual survival through calling and membership. Interaction in spiritual leadership theory, unlike in theories on cognitive leadership (where the efficiency of leadership depends on personal characteristics and behaviour), is understood as social interaction - the relationship between the leader and their followers. These relationships are revealed through a sense of meaning, vocation and membership. According to L. W. Fry (2003), a sense of meaning and vocation is the feeling that a person's life has meaning and is influential. Members of an organisation feel that their work has an impact on people's lives and it is significant and meaningful to them. Membership is the feeling that a person is understood and appreciated. Members of an organisation feel that they and their work are appreciated by colleagues and thus they are respected. Therefore, the member feels that in he/she is appreciated both as an individual and a professional in a certain field. Therefore, a strong sense of belonging to a team appears. G. W. Fairholm (1997) claims that "We need to focus on interactive communities of enabled moral leaders and followers. We need to engage the people making up these communities in meaningful work, in work that ennobles them and their colleagues and customers. Our workplace are communities in which many of us live much of our productive lives. We need, therefore, to know what we can about how to make work communities not only productive, but personally inspiring". Therefore, membership includes cultural and social structures, which reveal the person's key need - to be understood and appreciated. The feeling of being understood and appreciated depends mostly on personal relationships, formed through social interaction, i.e., membership. Employees value their relationships and the opportunity to feel as members of a larger community, the experience of interconnectedness (Pfeffer, 2003). Membership in social groups expands understanding of the individual and draws them into a network of social relations, which last as long as the group has influence. According to W. A. R. Horton (1950), "We grow greater, longer lived, more meaningful in proportion as we identify ourselves with the larger social life that surrounds us" (in: Fry, 2003).

A prerequisite of spiritual leadership is a spiritual leader - one who uses his vision as a mechanism for matching individual and organisational values. G. W. Fairholm (1998) claims that the leader's vision is a spiritual, not operational formula. People commit when they accept their manager on the basis of their values, needs, beliefs, habits and actions. Vision covers the general set of values, bringing people together into a community (Ferguson, Milliman, 2008). Therefore, leaders that rely on values bring these same values into the organisational context. They lead not through orders, but core values, showing what the company aims to become. The more these values reach the core values of the employees themselves, the more they encourage individual decisionmaking and self-improvement. Therefore, 
values can act as a critically important link between the organisation and its people. They determine why people work in the first place. In performing their roles, managers-leaders concretise their values in their organisations' culture. The same can be said about an organisation's spirituality. Managers are more likely to utilise their personal spiritual values in making decisions (Konz, Ryan, 1999). To preserve an organisation's spirituality, spirituality of managers is a necessity. The manager's spirituality should guide them in choosing what to do. Their actions should give life to spirituality. Their spirituality also determines the choices of employees. Therefore, this study reveals the experiences of leaders that arise from their core assumptions.

However, even though leadership is extensively researched in various areas of science, spiritual leadership in management remains a new phenomenon with not much empirical research, yet having great theoretical and practical relevance. The lack of empirical research demonstrating how spiritual leadership manifests in business culture, together with the need for spiritual leadership in these organisations, leads us to look for new aspects of spiritual leadership expression. Therefore, the problem of research is formulated as: What properties of organisational culture are evoked by spiritual leadership? The aim of research is to reveal experiences of the spiritual leader's interaction with employees in business organisations with particular focus on the Lithuanian context.

\section{Methodology}

The methodology for this study is based on post-modern philosophical provisions, an interpretive paradigm of the cognition of reality, and the strategy for qualitative research on the subject of phenomenological knowledge.

\section{Sample}

The interview was carried out with leaders, selected during the study on leader spirituality level assessment (for more details, see: Bakanauskiene, Katiliene, 2012), whose general spirituality estimate was the highest. Such a sampling of respondents was chosen with the aim to ensure the reliability of the study data. Ten toplevel managers of ten companies were interviewed.

\section{Method}

The hermeneutic phenomenological approach was selected (Lindseth, Norberg, 2004). It includes traditions of phenomenology as descriptive methodology used to study and describe phenomena as they appear in the experienced world in order to identify and disclose their meaning, and hermeneutics (Ricoeur, 2000) which allows perceiving the interview text and relating it to what is being said in the interview, as well as the meaning contained in the text.

Hence, the phenomenological hermeneutic method was selected as the data analysis method for a qualitative study, while an interview tool was created based on the key assumptions identified in E. Shein's (1985) organisational culture model.

Data collection. Interviews were selected as the instrument for collecting the data for this research. The interview technique - an individual, semi-structured interview. Interviews with the respondents 
were held in free-form, based on questions prepared ahead of time. E. Schein's (1985) already-mentioned core assumptions were selected as the basic building blocks for the semi-structured interview. The character of human nature, the nature of human relationships, the nature of human activity, the nature of reality and truth, the nature of time and space - these were the basis for the formation of the qualitative study's interview instrument.

Data analysis. After meeting with the respondents, the interviews were first of all transcribed. After reading them, a na- ive understanding was formed. Below is provided an example of the formulation of a naïve understanding of the interview text (Table 1).

After the naive reading, the text was then divided into meaningful units (which are abbreviated) and their sub-themes, isolating themes and the main issues (they have been tested by comparing them with the naïve understanding). Finally, the text was read one more time, considering the topics by comparing them with literature on living experience, and, finally, a clear understanding was formed (see Table 2).

\section{An example of a structural analysis of the narrative}

\begin{tabular}{|l|l|}
\hline \multicolumn{1}{|c|}{ Text } & \multicolumn{1}{|c|}{ Naïve understanding } \\
\hline $\begin{array}{l}\text { <...'An example would be initiative - you set the direc- } \\
\text { tion, as in one or other situation or in this relationship in } \\
\text { general, and the employee has to follow. You suggest the } \\
\text { direction, not force it, and then you hold a meeting and the } \\
\text { employee more or less stays in the direction suggested by } \\
\text { their manager. I, for example, have to be like this, as then the } \\
\text { organisation would not have a direction, it would be tossed } \\
\text { about in the wind'...> }\end{array}$ & $\begin{array}{l}\text { Employees work purposefully, agreeing with their } \\
\text { leader's choice for the organisation's direction. }\end{array}$ \\
\hline
\end{tabular}

\section{An example of a structural analysis of the narrative}

\begin{tabular}{|l|l|l|l|}
\hline \multicolumn{1}{|c|}{ Meaning unit } & \multicolumn{1}{|c|}{ Condensation } & Sub-theme & Theme \\
\hline $\begin{array}{l}\text { <An example would be initia- } \\
\text { tive - you set the direction, as } \\
\text { in one or other situation or in } \\
\text { this relationship in general, } \\
\text { which the employee has to fol- } \\
\text { low. You suggest the direction, } \\
\text { not force it, and then you hold } \\
\text { a meeting and the employee } \\
\text { more or less stays in the } \\
\text { direction suggested by their } \\
\text { manager. I, for example, have } \\
\text { to be like this, as them the } \\
\text { organisation would not have } \\
\begin{array}{l}\text { a direction, it would be tossed } \\
\text { about in the wind...> }\end{array}\end{array}$ & $\begin{array}{l}\text { purposully, agreeing } \\
\text { with the leader's choice } \\
\text { for the organisation's } \\
\text { direction }\end{array}$ & $\begin{array}{l}\text { The leader's power to } \\
\text { steer competent employ- } \\
\text { ees, aware of their value, } \\
\text { in the right direction }\end{array}$ & $\begin{array}{l}\text { Targeted actualisation } \\
\text { of employee activities }\end{array}$ \\
\hline
\end{tabular}


Tool. Aiming to choose the appropriate method for the spirituality-oriented business' signs of organisational culture identification test, the variety of organisational culture definitions and assessments were evaluated on the basis of B. Stiftung's (2007) three distinguished conceptualisation basics. Each of these perspectives is based on a different paradigm, which determines different assumptions about culture and its different evaluation methods (Stiftung, 2007) (see Table 3).

Since spiritual leadership consists of values, attitudes and behaviour, in aiming to develop the spirituality of the leader and others (this spirituality comes from vocation and membership (Fry, 2003)), in order to reveal which of the features of organisational culture are revealed in the presence of spiritual leadership, it was relied on E. Schein's model of the organisational culture levels and an analysis of the core assumptions, structuring the features of spiritually-oriented organisational culture in accordance with the aspects of the expressions of spiritually-oriented organisational culture, as distinguished by D. Zohar \& I. Marshall (2004).

Based on the anthropologists A. L. Kroeber and C. Kluckhohn (1952), E. Schein (1985) studied six deeper dimensions, according to which the core assumptions are formed: the nature of reality and truth, the nature of space, the character of human nature, the nature of human activity, and the nature of human relationships. E. Schein's (1985) cultural model was selected because it is consistent, widely used in both research and practice. He differentiated various levels and different components, paying more attention to the core assumptions (Stiftung, 2007). This model is suitable for examining organisational culture in a metaphorical manner.

\section{Three different perspectives of culture}

\begin{tabular}{|l|l|l|l|}
\hline & \multicolumn{1}{|c|}{ Culture as a variable } & \multicolumn{1}{|c|}{ Culture as a metaphor } & Culture as a dynamic construct \\
\hline $\begin{array}{l}\text { Assumptions } \\
\text { about culture }\end{array}$ & $\begin{array}{l}\text { Culture is an organisa- } \\
\text { tional variable that can } \\
\text { be manipulated. }\end{array}$ & $\begin{array}{l}\text { Culture is a metaphor for } \\
\text { understanding life in organi- } \\
\text { sations; organisational reality } \\
\text { is socially and symbolically } \\
\text { constructed. }\end{array}$ & $\begin{array}{l}\text { Culture is a dynamic construct; } \\
\text { organisational reality is socially } \\
\text { constructed and organisations } \\
\text { produce culture (including cul- } \\
\text { tural artefacts). }\end{array}$ \\
\hline $\begin{array}{l}\text { Predominant } \\
\text { interest in } \\
\text { culture }\end{array}$ & $\begin{array}{l}\text { Social facts/ } \\
\text { rational-mechanistic } \\
\text { naging, controlling and } \\
\text { changing the relevant } \\
\text { culture variable for best } \\
\text { performance. }\end{array}$ & $\begin{array}{l}\text { Interpretative } \\
\text { of a particular cultural setting } \\
\text { with a focus on organisational } \\
\text { symbolism. }\end{array}$ & $\begin{array}{l}\text { effective culture-aware manage- } \\
\text { ment ("tapping the culture poten- } \\
\text { context of an organisation for } \\
\text { tial for competitive advantage). }\end{array}$ \\
\hline $\begin{array}{l}\text { Assessment of } \\
\text { culture and its } \\
\text { purpose }\end{array}$ & $\begin{array}{l}\text { Focus on questionnai- } \\
\text { res and visible tools to } \\
\text { identify (sub)variables } \\
\text { that can be manipulated. }\end{array}$ & $\begin{array}{l}\text { Ethnography, story-telling, } \\
\text { in-depth interviews, discour- } \\
\text { se analysis to render rich } \\
\text { descriptions of a particular } \\
\text { cultural setting. }\end{array}$ & $\begin{array}{l}\text { Multiple methods; qualitative } \\
\text { and quantitative; perceptions and } \\
\text { observations, triangulation. }\end{array}$ \\
\hline
\end{tabular}




\section{Findings}

This topic reflects the experience of leaders, arising from their core assumptions revealed through targeted actualisation of employee activities, satisfaction, meaningful work, experience of organisational identity, leader-instigated sense of community, understanding and appreciation, employee awareness (Table 4).

This feature is expressed through targeted actualisation of employee activities by the leader's power to direct competent employees, being aware of their value, into the right direction. This is implemented through:

- presenting an idea/vision as a product of common thought activity, encouraging employees to work more efficiently;

- inspiring and encouraging employees to engage in targeted activities, selecting the best activities/functions for them;

- indicating the employee's limitations and expectations in the context of the company's culture, as well as encourage change;

- noticing good employees and providing them with the necessary working place, for their work to be brought to life without losing employees.

As a result, the company's employees work purposefully, accepting the leader's chosen direction for the organisation. When employees' work is focused and consistent, a result is always reached, as there is no break in the direction and it is not changed ahead of time. Besides, as the survey results show, the success of the organisation is related to consistent and focused employee work. The employees feel like they voluntarily joined the activities of the organisation, all of them aiming for a certain goal. Employees are individuals who need to be pointed in the right direction, yet they are not underestimated because of this. Leaders select for their teams only those employees who can go with the flow and who know their worth. Thus, the organisation's direction is clear for all and personally related to each employee.

Satisfaction is expressed through the mutual satisfaction of the leader and their employee. The leader knows their employees - their strengths and weaknesses, their attitude. Mutual understanding and communication is highly valued at companies. Mutual respect and tolerance is also present in many organisations: "<...>there has to be a basis on respect, yes? Respect needs to be mutual and, in principle, everyone needs to be respected as they are" (VII.1R). Therefore, a leader who communicated tries to do right with others and themselves. Humiliation of employees is not tolerated at companies: "I try to be as tolerant as possible, but sometimes it doesn't work out... You can criticise a person, shoot down their bad actions or poor work, but in no way is it OK to humiliate the person, their dignity, through discrediting their bad conduct" (VI.10R). Fear inhibits the creativity of employees and increases indifference. Therefore, at these companies leaders encourage positive behaviour, based on mutual respect and tolerance.

Meaningful work is expressed through common understanding of the purpose of the leader and the follower's success. "<...> it would be a good thing if people could themselves understand what it means to be successful. And another thing - it would be a good thing if managers could understand what success means for a person" (I.4R). It's not enough for an employee to have a 
Table 4

"Interaction of the leader and the followers" in the spiritually-oriented organisational culture

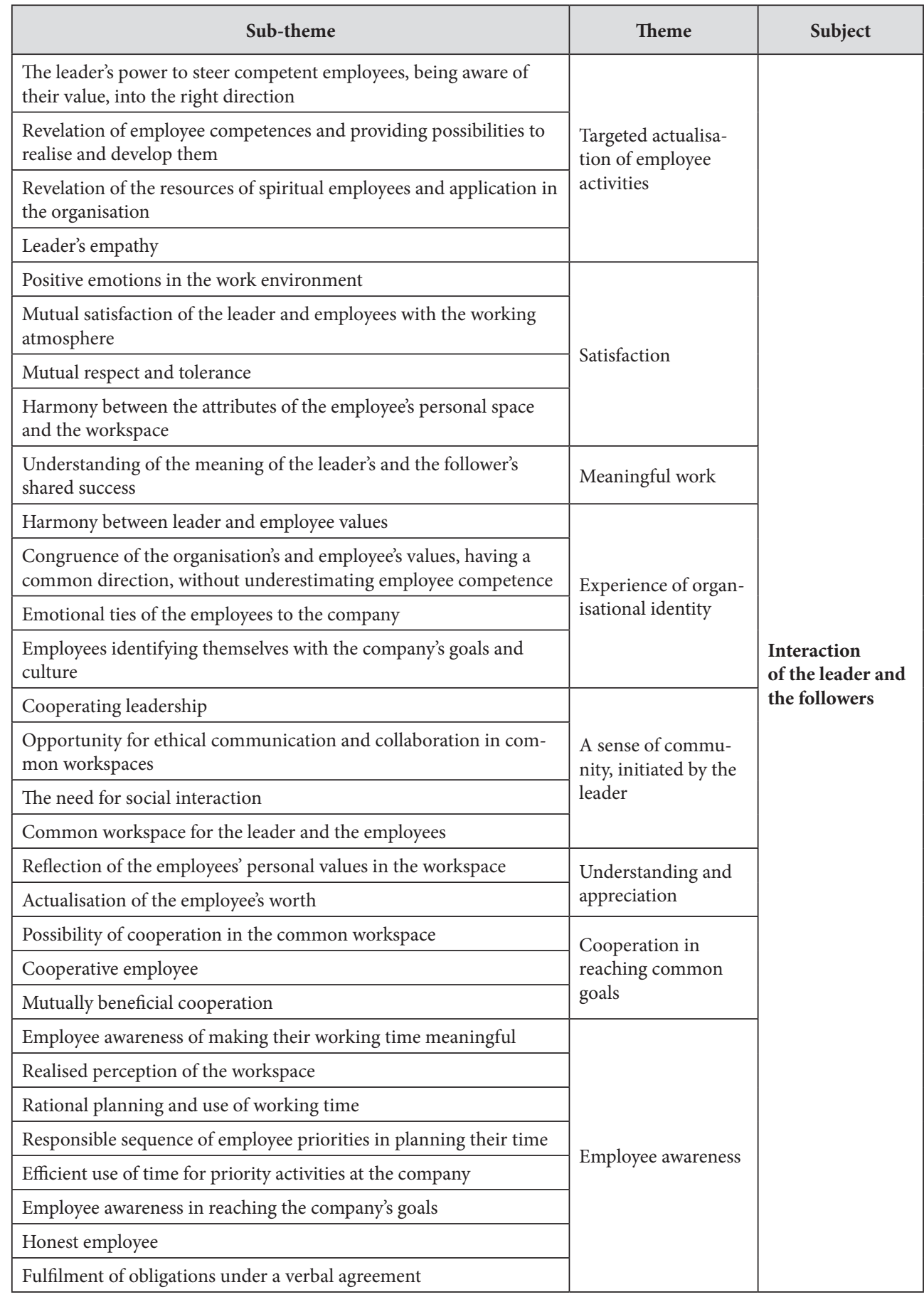


personal mission in a specific organisation. It is necessary for them to be understood, supported by their leader, and encouraged to work within the organisation in pursuit of a common goal: "they have their mission, their target. This is when a certain environment is necessary for the manager, one who would accept this person with their mission, maybe even put in an effort to highlight it and help that person understand it. Then, within the limits of the organisation's frames, allow that person to be involved in that activity and thus perform those activities that would allow them to achieve to the maximum their goals in life" (I.4R). Then an employee, in performing their activities, feels useful and needed at the organisation. This is " $<$...> one of the motivating factors so that they wouldn't feel like just a cog in the wheel, but rather a social creature that benefits their organisation, their community..." (VIII.7R).

In examining the experience of organisational identity, company leaders reveal that employees at their organisations feel satisfaction in reaching the organisation's goals and they know their worth at the organisation. An employee is a person who, through collaboration and equating their own goals to the goals of the organisation, contributes to the organisation's welfare. Through the employees' emotions, the leader notes how the employees undergo the company's success: "<...>it's the feeling that the situation is improving - this is widespread in the company... It is very much prevalent here<...>" (VIII.6R); introducing a new product to the market: "<...>that's probably the feeling when an idea becomes reality, a real product and sales - later we can celebrate this together" (VIII.2R). Employees, as a team, identify themselves with the company's joys and sorrows, so to say. Employees also have the opportunity to express their opinion as to why they like working at the company, providing feedback to one another. A positive working atmosphere is present in the company, as employees feel that they have contributed to the company's results. Employees are connected by the company's common goal through focused planning and realisation of activities. When feeling like members of the company "family", employees show their creativity and are open to innovations.

An activated sense of community is revealed through the collaborative leader's behaviour and motives. This is expressed through bringing together a team and working with it. The leader feels as one of the team's members. " $<$...>if I wouldn't have a team, I would be nobody. No matter how much I know, how much knowledge I have, how much I study the steps to success" (I.5R). The follower and the leader work together: "something needs to be done: 'Think about it. They then come and present something or other, we sit down and discuss it, perhaps argue" (I.10R). Managers create opportunities for ethical communication and collaboration in common workspaces. The workspace is divided in such a way that it wouldn't hinder individual work, at the same time creating opportunities for collaboration and good communication. Often employees have the opportunity to choose the colleagues with whom they would like to work in the workplace: "we go over and solve everything together. There aren't any big problems" (IV.8R). Not only functional division of workspaces is important, but also a positive work climate, achieved through bringing together in the same space those employees who don't conflict with each other. 
To be understood and appreciated is a separate sub-theme, since leaders value their employees as "exceptional people" (VIII.5R). Therefore: "employees feel that they are noticed, appreciated and that they are properly awarded for their efforts. I don't have in mind financial remuneration, but in general - both moral and financial satisfaction" (VIII.3R). When working in an organisation, both leaders and employees feel appreciated. Employees have an authority in both professional and honest communication among their colleagues: "<...> both in professional and human qualities<...>” (X.10R). For many years employees work in the same company, as there is a good working atmosphere and they are appreciated: "if people have worked here for so many years, then it means that we have these relationships, there is no constant tension and people's needs are fulfilled - financial and otherwise" (VIII.9R). But for there to be mutual understanding and appreciation, values are necessary - values that are acceptable to all members of the organisation. Managers notice that an understanding of the right way to communicate depends on the individual's values, which they bring with them and which impact their further career. Leaders also hold Christian values in high regard: "we are a Christian country, and we are mainly Catholics, something that shouldn't be forgotten... We shouldn't forget that the foundation of our whole society stands on this, so I think that it's right that such values are our roots, in a sort of general sense" (VII.9R). Those values impact the organisation's success and create a certain environment wherein the employee can follow them and be understood. This is expressed through, for example, when an employee doesn't stir trouble among their colleagues with ru- mours and intrigue. Employee relationships are based on Christian, or at least ethical, norms.

Collaboration in seeking a common goal is expressed through mutually beneficial cooperation, wherein the right decisions are considered a victory for all sides involved.

Employee awareness of reaching the company's goals comes to life through setting and knowing one's personal goals, through self-control, the ability to change quickly and accept new ideas in pursuit of the company's goals, operative problemsolving. Awareness is connected to worker integrity, which is the most desirable trait among employees by leaders: " $<\ldots>$ in first place I would hold an honest employee" (X.8R). An employee needs to be honest: "in one sentence - you should be clean before God" (X.2R). From the experience of leaders we can quote that " $<$...> it is possible to work honestly, as strange as it may seem, it is possible to pay honest wages and pay suppliers on time, to satisfy the client, please the shareholders" (X.2R) and state that honesty is not just an aspiration, but a real, existing value in many companies. Therefore, it is perfectly natural that in such environment employees efficiently use their working time for priority activities. Working hours are carefully planned, as this is related to the feeling of responsibility: "<...> when you have a feeling of responsibility, then time, well, I don't know, it somehow is set up in your pace, according to your abilities, priorities. But it is very important to not get lost in this time, to not grow tired, overwork. Time spent needs to be cheerful, rational, and meaningful" (III.5R). The results of the study highlight punctuality and respect as a sign of good manners. Therefore, time needs to be carefully planned, as it is related to 
punctuality and mutual respect. So, the study results reveal that employees consciously give a sense of purpose to their working time at a company. Time is not strictly divided into working hours, but it has to be meaningfully used in their work. Employees are responsible for using their working time meaningfully and the leader does not associate working hours with efficiently used time: "I base everything on consciousness; this means that a person can have all sorts of circumstances. We are mostly made up young people, particularly young men, aged 30-40 - that's the most productive age, but many of them have school-aged children, they have to drive then to school in the mornings, maybe they get stuck in traffic, and standing every day at the door looking at the clock and demanding that they be on time is something that we don't do. I know that if they are late they will stay 10-15-30 minutes longer after work <...>" (III.10R). Time is flexibly divided into working hours; however, it must be meaningfully used for work activities: "I encourage people to not just sit out the necessary hours, but actually complete their work. Hours are relative. I even allow employees to choose their working hours. They can come in at 9 or 7 AM, they can work on the weekend if they want a free day some other time, they can... Well, in other words, we are very flexible" (III.2R). Respectively, when a company has such a level of employee awareness, fulfilment of obligations under an oral agreement is taken for granted.

Another aspect, highlighted by leaders and related to employee awareness, is perception of the awareness of their working space. The workspace is given high priority: the space for employees and clients should be comfortable both in the physical sense and also gladden employees with assessments and achievements. If employee awareness is related to their honest activities and responsibility in achieving the company's goals, their working time and workspace allow them to efficiently achieve these goals. Time in an organisation is not working hours, but maximum effort.

The findings lead us to a conclusion that the results of the qualitative study allow us to identify which features of organisational culture are manifested when the manager of a company is a spiritual leader.

\section{Discussion}

To this day, there is only one theory of spiritual leadership empirically tested in various environments. This theory was created by L. W. Fry (2003, 2005). More than 100 organisations (including schools, military divisions, cities, the police, and non-profit organisations) were studied the range was between 10 and 100. These studies proved the spiritual leadership model, as well as reliability and suitability of its indicators. The results show strong and positive influence of spiritual leadership on employee satisfaction with their lives, organisational commitment, and growth in productivity and sales (Fry, Matherly, 2006; Fry, Slocum, 2008; Fry et al., 2005, 2007; Malone, Fry, 2003). In this theory, the interaction of followers and the leader reflects the revelation of meaning and vocation, and a sense of membership (Fry, 1998). The results of the study described in this article show that meaning and vocation in the context of organisational culture are revealed through employee awareness and meaningful work. Employee awareness, discovered during this study, shows that honest employees 
work at organisations, they comply with their commitments (even verbal ones), responsibly plan working hours in line with their priorities, consciously achieve the company's goals. Since understanding of the meaningfulness of the company's work is the same for both the manager and the employee, it is purposeful to aim for the company's goals.

In the context of leadership theory, community means that its members care about the lives of their colleagues, their growth, competences and happiness not just as a means to increase motivation and profit, but as inherent values (Fairholm, 1997). Therefore, in the organisational context, the group members can realise their beliefs by being involved and participating in the organisation's activities. One shouldn't be surprised that in harmoniously working groups positive emotions arise as a result of realised beliefs, and then in turn are transferred to the organisation itself (Rojas, 2005). Spiritual leadership, according to G. W. Fairholm (1998), means the formation of harmony between different, sometimes conflicting, organisational, human, system and programme groups. This is an attempt to create a community, to unite everyone. It is an assignment to create values, beliefs and action principles that have deep roots and are acceptable to interested persons and would encourage them. Spiritual leadership recognises that all people aim to freely act in accordance to their own reality and at the same time participate in in groups comprised of similarly-thinking people. The performed survey does not contradict such reasoning. People have to live in a social stratum where they can communicate with other and realise themselves, on the basis of values. The study's results show that membership in the context of organisational culture is revealed through the leader-instigated sociality, understanding and appreciation. Leader-instigated sociality is expressed through several features of spirituality-oriented organisational culture. In these organisations, leaders are first and foremost collaborating managers. Opportunities for ethical collaboration are created in the organisation's common workspaces. Employees have the opportunity to meet their social needs for communication through collaboration and teamwork. Principles and practice, supporting the main need that people have to "belong" (to be understood and appreciated), are dedicated towards encouraging people to follow their heart. "The practice of encouraging the heart is not about glad-handing and backslapping, gold stars, and payoffs. Encouragement is viewed as absolutely essential to sustaining people's commitment to organizations and outcomes. It is about the hard work it takes to get extraordinary things done in organizations, and it is about ways to enhance your own ability in-and comfort with-recognizing and celebrating the achievement of others" (Kouzes, Pozner, 1999). The results of the study revealed that employees feel understood and appreciated when the values that they bring to the organisation are not hidden, but rather accepted and applied (if they are in line with the organisation's values). Also, employees at such organisations know they value and feel valued by both their manager and colleagues. This is expressed through professional authority and the authority of sincere interaction with one's colleagues. Also revealed is the fact that organisational culture expresses mutual satisfaction of leaders and colleagues. Encouragement is seen as 
something that is absolutely necessary to preserve people's dedication to the organisation and its performance. Hard work goes hand in hand with the desire to achieve exceptional results, it is constant improvement of the ability to recognise and appreciate the achievements of others (Kouzes, Pozner, 1999). The study confirms that employees at the organisations under review, according to the managers' experiences, feel that they are fairly appreciated both in non-financial means of encouragement, and through their wages. Leaders feel appreciated through acknowledgement and the opportunity to act in their desired direction and in their favoured field. They are all united by a common vision and a common goal. Experience of organisational identity in the context of organisational culture is characterised by commitment to the company. The study's results reveal that companies are dominated by their employees' emotional attachment to the organisation and employees identify themselves with the company's goals and culture. A significant impact is had by similarity between the leader's and follower's orientation, as well as their approval of the company's vision and goals. This leads to a desire to collaborate and achieve common goals. According to the study, such collaboration is mutually beneficial. Moreover, perfect conditions appear for employees, i.e., conditions that promote a sense of community and collaboration.

\section{Conclusions}

The results of the empirical research showed that expression of the spiritual leaders' interaction with employees could be evidenced by organisational culture properties, which emerge in organisations under a spiritual leader's activity. The spiritual leaders' interaction with their employees manifests through calling and membership. It means that clear experiences in the expression of such interaction in business organisations opened opportunities for organisational culture, giving rise to such features as targeted actualisation of employee activities, satisfaction, meaningful work, experience of organisational identity, leader-brought sense of community, understanding and appreciation, employee awareness. To sum up, it could be argued that having developed the mentioned features in the organisation the leader will be able to integrate his/her worldview into the organisational culture, which consequently will influence employees' behaviour through employee motives, thus triggering all the desired cultural manifestation. 


\section{References}

1. Barvydienè, V. (2015). Lyderio charizma. - ISM vadybos ir ekonomikos universitetas.

2. Fairholm, G. W. (1997). Capturing the heart of leadership: spirituality and community in the new American workplace. - Westport, CT: Praeger, 248 p. doi: 10.5860/choice.35-2205.

3. Fairholm, G. W. (1998). Perspectives on leadership: from the science of management to its spiritual heart. - Westport, Conn: Quorum.

4. Ferguson, J., Milliman, J. (2008). Creating Effective Core Organizational Values: A Spiritual Leadership Approach // The International Journal of Public Administration. Vol. 31, No. 4, pp. 439-459. doi: 10.1080/01900690701590835.

5. Fry, L. W. (2003). Toward a Theory of Spiritual Leadership // The Leadership Quarterly. Vol. 14(6), pp. 693-727. doi: 10.1016/ j.leaqua.2003.09.001.

6. Fry, L. W. (2005). Toward a Theory of Ethical and Spiritual Well-being, and Corporate Social Responsibility through Spiritual Leadership, In R. A. Giacalone (Ed.), Positive Psychology in Business Ethics and Corporate Responsibility, pp. $47-83$.

7. Fry, L. W., Slocum, Jr., John, W. (2008). Maximizing the Triple Bottom Line through Spiritual Leadership // Organizational Dynamics. Vol. 37, No. 1, pp. 86-96. doi: 10.1016/ j.orgdyn.2007.11.004.

8. Horton, W. R. (1950). God (9th printing). - New York: Association Press.

9. Katilienė, R., Bakanauskienè, I. (2012). Expression of Spiritual Leadership in Lithuanian Businesses // Organizaciju vadyba: sisteminiai tyrimai. No. 64, pp. 53-67. doi: 10.7220/ mosr.1392.1142.2012.64.4.

10. Konz, G. N. P., Ryan, F. X. (1999). Maintaining an Organizational Spirituality: No Easy Task // Journal of Organizational Change
Management. Vol. 12(3), pp. 200-210. doi: 10.1108/09534819910273865.

11. Kouzes, J. M., Posner, B. Z. (1999). Encouraging the Heart: A Leader's Guide to Rewarding and Recognizing Others. - San Francisco: JosseyBass.

12. Kroeber, A. L., Kluckhohn, C. (1952). Culture: A critical review of concepts and definitions. - New York: Vintage Books. doi: 10.2307/2087565.

13. Lindseth, A., Norberg, A. (2004). A Phenomenological Hermeneutical Method for Researching Lived Experience // Scandinavian Journal of Caring Sciences. Vol. 18, pp. 145-153. doi:10.1111/j.1471-6712.2004.00258.x.

14. Pfeffer, J. (2003). Introduction to the Classic Edition, In Pfeffer, J. and Salancik, G. R., The External Control of organizations: A Resource Dependence Perspective (classic edition). Stanford University Press, Stanford, CA.

15. Ricoeur, P. (2000). Interpretacijos teorija. Diskursas ir reikšmès perteklius. - Vilnius: Baltos lankos.

16. Skaržauskienè, A. (2010). Sisteminis mąstymas organizacijų valdyme. Monografija. - Mykolo Riomerio universitetas, Vilnius.

17. Stiftung, B. (2007). Assessment, Evaluation, Improvement: Success through Corporate Culture, Typesetting and Print: Hans Kock Buch- und Offetdruck GmbH, Bielefeld, 168 p.

18. Šilingienè, V. (2012). Lyderystè. - Kaunas: Technologija. doi: 10.5755/e01.9786090206287.

19. Schein, E. (1985). Organizational Culture and Leadership. - San Francisco, CA: Jossey-Bass, 358 p. doi: $10.1002 / \mathrm{hrm} .3930240312$.

The paper submitted: June 20, 2017

Prepared for publication: December 10, 2017 


\title{
Rasa KATILIENÉ
}

\section{DVASINGŲ VADOVŲ SĄVEIKOS SU DARBUOTOJAIS PATYRIMAI VERSLO ORGANIZACIJOSE}

\author{
S a n t r a u k a
}

Darbuotojų veiklos motyvai bei elgsena buvo ir išlieka aktuali tiek organizacijų vadybos praktikoje, tiek mokslo srityse, ieškant efektyvesnių priemonių, skatinančių darbuotojus siekti immonès tikslų. Verslo organizacijose vis labiau siekiama įtvirtinti kultūros bruožus, kurie galètų pakeisti dabartinius dominuojančius darbuotojų motyvus veikti, tokius kaip baimè, godumas, pyktis ir savęs įtvirtinimas, i pozityvesnius, tokius kaip tyrinejjimas ir mokymasis, bendradarbiavimas, vidinė stiprybė ir meistriškumas. Šie pozityvūs veiklos motyvai susiję su dvasine lyderyste, kuri (vis labiau įrodoma) leidžia atsisakyti senų veiklos modelių ir senų mąstymo būdų bei judèti aukštesnès darbuotojų motyvacijos link. Todèl dvasinių vertybių integravimas jł organizacijos kultūrą yra nauja paradigma, radikaliai keičianti tradicinị mąstymą apie verslo filosofinius pamatus ir praktiką. Žinant organizacijos kultūros bruožus, formuojančius aukštesnius darbuotojų veiklos motyvus, galima atskleisti darbuotojų elgsenos modelius. Tai skatina analizuoti įvairius reiškinius, susijusius su tarpasmeniniais lyderio ir sekejų santykiais darbe. Naujosios paradigmos lyderystès teorijos praplečia lyderystès diapazoną emociniais, socialiniais, etiniais ir moraliniais poveikio sekejjams aspektais. Jose sujungiamos sociologijos, psichologijos, filosofijos žinios ir kuriamos naujos lyderystès sampratos apimant ir tarpusavio santykius. Remiantis šiuolaikinèmis lyderystès teorijomis, tarp jų ir dvasinès, lyderystę galima apibūdinti ne tik lyderio asmenybès jèga, bet ir sąveika su sekejais, vizija, orientuota $\underset{i}{\mathrm{i}}$ tam tikras vertybes, ir veiklos rezultatus. Todèl straipsnyje pristatomas tyrimas, kurio tikslas - atskleisti dvasingu vadovu squeikos su darbuotojais organizacijų kultūroje patirtis. Tyrimo rezultatas - lyderio ir sekeju squeika Lietuvos vidutinio dydžio organizacijų kultūroje kaip dvasingų vadovų patyrimas.

Tyrimas aprašomas remiantis Paul Ricoeur interpretacijos teorijos paremtu A. Lindseth (2004) ir A. Norberg (2004) fenomenologiniu-hermeneutiniu metodu, skirtu interviu tekstams interpretuoti. Taikant ši metodą, neformuluojami tyrimo objekto išankstiniai teiginiai (hipotezès). Vadovų patyrimus galima būtų apibūdinti kaip interviu metu sukonfigūruotą jų prefigūruotą gyvenamąji pasauli. Vadovų patirtys, igyjamos iš jų kertinių prielaidų, atsiskleide per: kryptingq darbuotoju veiklos iprasminima, pasitenkinima, prasminga darba, organizacinio tapatumo potyri, lyderio jiveiklinta bedruomeniškumą, supratima ir ivertinima, darbuotoju sq̨moningumą. Šie kokybinio tyrimo rezultatai leido identifikuoti, kokie organizacijos kultūros požymiai pasireiškia, kuomet įmonei vadovauja dvasingas lyderis. Straipsnyje aprašomo tyrimo rezultatai rodo, kad prasmè ir pašaukimas organizacijos kultūros kontekste atsiskleidžia per darbuotoju sąmoningumą, prasminga darba. Tyrime ịvardytas darbuotoju sąmoningumas rodo, kad organizacijose dirba sąžiningi darbuotojai, kurie laikosi ịsipareigojimų (net žodinių), atsakingai planuoja darbo laiką prioritetine seka, sąmoningai siekia įmonès tikslų. Kadangi įmonèje atliekamo darbo prasmiu suvokimai yra bendri tiek vadovui, tiek darbuotojui, tai siekti įmonès tikslų yra prasminga. Atliktas tyrimas neprieštarauja dvasinès lyderystès nuostatoms, jog žmogus turi gyventi sociume, kad galètų bendrauti su kitais bei realizuoti save, vadovaudamasis vertybemis. Tyrimo rezultatai rodo, kad narystè organizacijos kultūros kontekste atsiskleidžia per lyderio ịveiklintą bendruomeniškumą, supratima ir ivertinima. Lyderiai šiose organizacijose visų pirma yra bendradarbiaujantys vadovai. Etiško bendradarbiavimo galimybès sudarytos organizacijos bendrose darbo erdvése. Darbuotojai turi galimybę patenkinti bendravimo socialinius poreikius per bendradarbiavimą ir komandinị darbą. Principai bei praktikos, palaikančios pagrindinị žmogaus poreikị priklausyti - būti suprastam ir ivertintam skirtos skatinti žmones vadovautis širdimi. Tyrimo rezultatai atskleidè, kad darbuotojai jaučiasi suprasti ir ịvertinti tada, kai jų atsineštos j organizaciją vertybès nèra slepiamos, bet priimamos ir taikomos organizacijoje (jei neprieštarauja organizacijos vertybėms). Taip pat darbuotojai šiose organizacijose jaučia patys savo vertę bei jaučiasi ịvertinti tiek vadovo, tiek kolegų. Tai išreikšta tiek per profesinị, tiek per nuoširdaus bendravimo su kolegomis autoritetą. Tyrimo rezultatai rodo, kad organizacijos kultūroje pasireiškia abipusis vadovo ir darbuotojo pasitenkinimas. Skatinimas laikomas absoliučiai būtinu, norint išlaikyti žmonių atsidavimą organizacijoms ir rezultatams. Tyrimas patvirtina, kad nagrinètų organizacijų darbuotojai jaučiasi sąžiningai juvertinti tiek nematerialiai, tiek per finansinị atlygị. Lyderiai jaučiasi ịvertinti per pripažinimą bei galèdami veikti norima kryptimi ir mėgstamoje srityje. Juos visus jungia bendra vizija 
ir tikslo siekimas. Organizacinio tapatumo potyris organizacijos kultūros kontekste pasireiškia ịsipareigojimu įmonei. Tyrimo rezultatai atskleidžia, kad įmonèse vyrauja darbuotojų emocinis prisirišimas prie organizacijos ir darbuotojai tapatinasi su įmonès tikslais ir kultūra. Tam didelę ittaką daro lyderio ir sekejų vertybinès orientacijos panašumas bei pritarimas i̇monès vizijai, tikslams. Tyrimas patvirtina, kad šis bendradarbiavimas yra abipusiškai naudingas, darbuotojams sudarytos puikios sąlygos, skatinančios bendruomeniškumą ir bendradarbiavimą. 